\title{
Human mesenchymal stem cell therapy promotes retinal ganglion cell survival and target reconnection after optic nerve crush in adult rats
}

\author{
Almir Jordão da Silva-Junior ${ }^{1,2,3^{*}}$ (D, Louise Alessandra Mesentier-Louro ${ }^{1,4}$, Gabriel Nascimento-dos-Santos ${ }^{1,2}$, \\ Leandro Coelho Teixeira-Pinheiro ${ }^{1,2}$, Juliana F. Vasques ${ }^{1,2}$, Luiza Chimeli-Ormonde ${ }^{1,2}$, Victor Bodart-Santos ${ }^{1,2}$, \\ Luiza Rachel Pinheiro de Carvalho ${ }^{1,2}$, Marcelo Felippe Santiago ${ }^{1,2}$ and Rosalia Mendez-Otero ${ }^{1,2,3}$
}

\begin{abstract}
Background: Optic-nerve injury results in impaired transmission of visual signals to central targets and leads to the death of retinal ganglion cells (RGCs) and irreversible vision loss. Therapies with mesenchymal stem cells (MSCs) from different sources have been used experimentally to increase survival and regeneration of RGCs.

Methods: We investigated the efficacy of human umbilical Wharton's jelly-derived MSCs (hWJ-MSCs) and their extracellular vesicles (EVs) in a rat model of optic nerve crush.

Results: hWJ-MSCs had a sustained neuroprotective effect on RGCs for 14, 60, and 120 days after optic nerve crush. The same effect was obtained using serum-deprived hWJ-MSCs, whereas transplantation of EVs obtained from those cells was ineffective. Treatment with hWJ-MSCs also promoted axonal regeneration along the optic nerve and reinnervation of visual targets 120 days after crush.

Conclusions: The observations showed that this treatment with human-derived MSCs promoted sustained neuroprotection and regeneration of RGCs after optic nerve injury. These findings highlight the possibility to use cell therapy to preserve neurons and to promote axon regeneration, using a reliable source of human MSCs.
\end{abstract}

Keywords: Central nervous system, Optic nerve injury, Nerve regeneration, Neuroprotection, Cell therapy, Mesenchymal stem cells

\section{Background}

Optic nerve injuries resulting from optic neuropathies, traumas, or tumors are characterized by optic nerve degeneration, resulting in partial to complete loss of vision [1]. These injuries specifically affect the RGCs, whose

\footnotetext{
*Correspondence: jordao.a@biof.ufrj.br

'Instituto de Biofísica Carlos Chagas Filho, Universidade Federal do Rio de Janeiro, Rio de Janeiro, RJ 21941-902, Brazil

${ }^{2}$ Instituto Nacional de Ciência e Tecnologia em Medicina Regenerativa-REGE NERE, Rio de Janeiro, RJ, Brazil

Full list of author information is available at the end of the article
}

axons form the optic nerve, and their cell bodies degenerate as a consequence of the injury [2]. For instance, glaucoma, the leading cause of RGC degeneration, affects more than 70 million people worldwide, 8 million of whom suffer irreversible bilateral blindness [3]. No clinical treatment is available to sustain RGC survival and promote their regeneration.

The ongoing search for therapies that promote RGC survival and axonal regeneration has impelled many in vitro and in vivo studies [4]. Intraorbital optic nerve crush is a wellestablished model that leads to progressive degeneration of

(c) The Author(s). 2021 Open Access This article is licensed under a Creative Commons Attribution 4.0 International License, which permits use, sharing, adaptation, distribution and reproduction in any medium or format, as long as you give appropriate credit to the original author(s) and the source, provide a link to the Creative Commons licence, and indicate if changes were made. The images or other third party material in this article are included in the article's Creative Commons licence, unless indicated otherwise in a credit line to the material. If material is not included in the article's Creative Commons licence and your intended use is not permitted by statutory regulation or exceeds the permitted use, you will need to obtain permission directly from the copyright holder. To view a copy of this licence, visit http://creativecommons.org/licenses/by/4.0/ The Creative Commons Public Domain Dedication waiver (http://creativecommons.org/publicdomain/zero/1.0/) applies to the data made available in this article, unless otherwise stated in a credit line to the data. 
RGCs, mostly by apoptosis [5-12]. Although RGCs enter a regenerative state after axonal lesion, by upregulating growth-associated protein 43 (GAP43) and activating transcription factor 3, among other factors [13-15], they do not successfully extend their axons beyond the lesion site [16]. Non-neuronal factors such as glial cells and matrix molecules [17-19] and intrinsic neuronal factors contribute to this regenerative failure [20-22]. Furthermore, optic nerve injury interrupts the connection with axonal targets such as the dorsal lateral geniculate nucleus (dLGN) and the superior colliculus (SC), which results in failure in shuttling trophic factors [3, 23, 24].

Several efforts have been made to enhance the regenerative potential of RGCs. For example, deletion of the phosphatase and tensin homolog (PTEN) and the suppressor of cytokine signaling 3 (Socs3) genes, individually or simultaneously $[11,25]$, significantly increased the regenerative capacity of RGCs after optic nerve lesion [26]. Axonal regeneration is further increased when PTEN deletion is combined with an inflammatory stimulus, inducing RGC regeneration up to the LGN, the suprachiasmatic nucleus and the SC, resulting in partial recovery of visual responses $[10,27]$. However, most of these approaches are based on Cre-recombinase techniques, which are not yet suitable for use as clinical therapies.

Cell therapies have emerged as a more viable alternative clinical approach in recent years. Transplanted cells can respond to signals from the lesion environment, activate neuroprotective and pro-regenerative pathways, and even overcome deleterious effects of inflammation $[28,29]$. Previous studies from our group have shown that cell therapy with adult bone marrow-derived mononuclear cells (BMMC) increases RGC survival in an optic nerve crush model for a short time period, and some axons can reach and establish synapses in the SC $[8,30]$. Alternatively, our group has shown that mesenchymal stem cells (MSCs) remain in the rat vitreous body for at least 18 weeks, providing prolonged neuroprotection to RGCs [6] and inducing strong axonal regeneration up to their brain targets [31]. Also, MSCs have been shown to protect RGCs in models of ische$\mathrm{mia} /$ reperfusion [32] and ocular hypertension [33-35], among others.

Compared to other stem cells, MSCs have several advantages, including a low risk of rejection, and simple isolation and culture [36, 37]. It has been suggested that MSCs act through paracrine mechanisms, either by releasing factors directly or from extracellular vesicles (EVs), membrane-covered structures that include microvesicles and exosomes [38-40]. EVs can transfer proteins, bioactive lipids, RNAs, and microRNAs, which can modulate entire signaling pathways $[38,39]$.

For future clinical studies, it is important to investigate the effects of human MSCs on RGCs after optic nerve injury. MSCs from human Wharton's jelly (hWJ-MSCs) have been suggested as a potential source for cell therapies because they are easily obtained and multiplied in vitro [36] and, as recently shown by our group, promote RGC survival in vitro by paracrine mechanisms [41]. In the present study, we found that a single intravitreal injection of hWJ-MSCs, cultured in the presence or absence of serum, was neuroprotective, but their EVs were not in the dose used here. Moreover, the neuroprotective effect was sustained for the long term after the crush injury, concomitant with axon regeneration up to dLGN and SC, as well as synaptic reconnection at the SC.

\section{Material and methods}

\section{Ethical considerations}

All procedures involving human-derived materials were approved by and followed the guidelines of the Institutional Human Ethical and Research Committee of the Clementino Fraga Filho Hospital of the Federal University of Rio de Janeiro. Umbilical cords were donated after the mothers signed informed consent forms, as described in previous studies [41-44]. Experiments with animals followed the US National Institutes of Health guidelines and were approved and monitored by the Institutional Animal Care and Use Committee of the Federal University of Rio de Janeiro.

\section{hWJ-MSC isolation and cultures}

Umbilical cords were collected in $200 \mathrm{~mL}$ of phosphatebuffered saline (PBS) with $1 \%$ antibiotics and fungizone (100 U/mL penicillin, $100 \mu \mathrm{g} / \mathrm{mL}$ streptomycin, amphotericin B, $250 \mathrm{~g} / \mathrm{mL}$; Life Technologies) at $4{ }^{\circ} \mathrm{C}$. hWJMSC were isolated as previously described [42, 43]. Small pieces of isolated Wharton's jelly were cut and digested for $16 \mathrm{~h}$ with collagenase type II $(200 \mathrm{U} / \mathrm{mL}$; Gibco, CA, USA) diluted in $100 \mathrm{~mL}$ Dulbecco's modified Eagle's medium F-12 (DMEM F-12; Gibco) with 1\% antibiotics at $37^{\circ} \mathrm{C}$, under slow agitation. The digested material was washed in PBS, and the cell pellet was resuspended and plated in $75-\mathrm{cm}^{2}$ plastic culture flasks in DMEM-F12 medium supplemented with $15 \%$ fetal bovine serum (FBS; Gibco) and 1\% of both penicillin/ streptomycin (Gibco). Cells were maintained with 5\% $\mathrm{CO}_{2}$ in atmospheric air at $37^{\circ} \mathrm{C}$. After $3-5$ passages, the cultures were highly enriched in hWJ-MSCs and were characterized by the expression of surface markers and differentiation potential as adipogenic or chondrogenic lineages [43].

To evaluate if serum deprivation (SD-) affects the therapeutic potential of hWJ-MSCs, the medium was withdrawn, the culture flasks were washed three times with PBS, and hWJ-MSCs were incubated with serumfree DMEM-F12 and antibiotics for $24 \mathrm{~h}$. For therapy, 
cells in both conditions were detached at $80-90 \%$ confluence, using trypsin-EDTA solution (0.25\% trypsin and $1 \mathrm{mM}$ EDTA, Gibco). The trypsin was inactivated with DMEM-F12 medium containing 15\% FBS, and the contents were washed three times with PBS by centrifuging for $5 \mathrm{~min}$ at $300 \times \mathrm{g}$, and the last time with Pulmozyme (recombinant human DNase I; $0.6 \mu \mathrm{L} / \mathrm{mL}$; Roche). Cell viability was assessed by trypan blue staining. A total of $5 \times 10^{5} \mathrm{hWJ}-\mathrm{MSC}$ or SD-hWJMSC was resuspended in $5 \mu \mathrm{L}$ of sterile PBS containing Pulmozyme for intravitreal injection.

\section{Isolation of hWJ-MSCs-derived EVs}

EVs secreted by hWJ-MSCs after $24 \mathrm{~h}$ in culture in serum-free medium were isolated as described previously $[43,45]$. The medium was collected and sequentially centrifuged at $2000 \times g$ for $20 \mathrm{~min}$ and $100,000 \times g$ for $2 \mathrm{~h}$ at $4{ }^{\circ} \mathrm{C}$ (Optima L-90 K ultracentrifuge; Beckman Coulter), and the pellet was resuspended in PBS. Our group has previously found that hWJ-MSCs-derived EVs include microvesicles (100-1000 nm) expressing CD70, CD90, and CD105, and not expressing CD46, HLA-DR, and hematopoietic markers, and exosomes $(30-150 \mathrm{~nm})$ expressing CD63, CD9, and CD81 [43]. A quantity of $8.65 \times 10^{9} \mathrm{EVs}$ in $5 \mu \mathrm{L}$ of PBS was aliquoted for injection, approximately equivalent to the quantity produced by $5 \times 10^{5} \mathrm{hWJ}-\mathrm{MSCs}$ in $24 \mathrm{~h}[43]$.

\section{Optic nerve crush and intravitreal injection}

Lister hooded rats (3 to 5 months old), with a mean weight of $200 \mathrm{~g}$ (females) and $300 \mathrm{~g}$ (males), were used in this study. Animals were housed with access to water and food ad libitum in a 12-h light/dark cycle, with all the procedures intended to minimize the number of animals used and their suffering. Animals were anesthetized with ketamine $(75 \mathrm{mg} / \mathrm{kg})$ and xylazine $(5 \mathrm{mg} / \mathrm{kg})$ injected intraperitoneally, and lidocaine was applied topically in the surgical region. Optic nerve crush was performed as previously described [8], briefly, at $1 \mathrm{~mm}$ behind the optic disc of the left eye with a forceps pressed on the optic nerve for $15 \mathrm{~s}$, avoiding the ophthalmic artery and vein. Immediately after crush, a $5-\mu \mathrm{L}$ suspension of $5 \times 10^{5} \mathrm{hWJ}$-MSCs or SDhWJ-MSCs, $8.65 \times 10^{9} \mathrm{EVs}$, or vehicle (PBS + DNase) was injected into the vitreous body using a $5-\mu \mathrm{L}$ Hamilton syringe at the limbus, avoiding injury to the lens. Before the injection, the same volume $(5 \mu \mathrm{L})$ was aspired in order to avoid an increase in the intraocular pressure. After surgery, the skin was sutured and lidocaine ointment was applied. Animals were kept warm and under supervision until they recovered from the anesthesia. Animals with damage to the lens or blood vessels were excluded from the analysis.

\section{RGC survival analysis}

To evaluate RGC survival after optic nerve crush, wholemounted retinas were immunostained with Tuj1 antibody, which identifies $\beta I I I$ tubulin in retinal neurons and is widely used as an RGC marker [6, 11, 25, 46]. Animals were perfused through the heart with ice-cold saline, followed by $4 \%$ paraformaldehyde in $0.1-\mathrm{M}$ phosphate buffer. Eyes were removed; retinas were dissected and washed 3 times with PBS with $0.5 \%$ Triton X-100 (Sigma; PBST-0.5\%), followed by a 30-min incubation with 5\% normal goat serum diluted in PBS. Retinas were then incubated with anti- $\beta$-III-tubulin antibody (Tuj1 mouse, Covance, $1: 250)$ in $250 \mu \mathrm{L}$ of PBST-2\% for $18 \mathrm{~h}$ at $4{ }^{\circ} \mathrm{C}$, washed with PBST-0.5\%, and incubated with Alexa488-conjugated anti-mouse IgG produced in goat and ToPro-3 (both 1:1000, Life Technologies), in $250 \mu \mathrm{L}$ of PBST-2\% for $2 \mathrm{~h}$ at room temperature. Retinas were washed 3 times with PBS and then flat-mounted with $10 \%$-Phenylenediamine (PPD; $1 \mathrm{mg} / \mathrm{mL}$ in PBS) diluted in $90 \%$ glycerol. All washes and incubations were performed using a slow orbital shaker.

For quantification, 20 confocal images (each $0.05 \mathrm{~mm}^{2}$ in area) of Tuj1-stained retinas were obtained using a confocal microscope (one optical section $2.5 \mu \mathrm{m}$ thick; $\times$ 40/0.8 Plan-NEOFLUAR oil-immersion objective; Zeiss LSM 510 Meta). Were generated images from 10 fields at $1 \mathrm{~mm}$ and 10 fields at $3.5 \mathrm{~mm}$ from the optic disc. The number of Tuj $1^{+}$cells was counted manually by a masked observer using Image J 5.2i (NIH, imagej.nih. gov, USA) and normalized by the number of RGCs in the contralateral retina. Statistical analysis was performed using a $t$ test to compare two groups, or oneway ANOVA with Tukey's multiple comparison test for more groups, in GraphPad Prism 6 (GraphPad Software Inc., San Diego, CA, USA).

\section{Axon staining and quantification}

After perfusion, optic nerves and brains were dissected, cryopreserved in a sucrose gradient $(10,20$ and 30\%) in $0.1 \mathrm{M}$ phosphate buffer ( $\mathrm{pH}$ 7.4), and embedded in optimal cutting temperature medium (OCT, Tissue-Tek, Sakura, Japan). Optic nerves and brains were sectioned longitudinally and coronally on a cryostat (Leica, Wetzlar, Germany) at 14 and $20 \mu \mathrm{m}$ thickness, respectively. Brain sections were collected from the optic chiasm to the posterior portion of the SC on gelatin-coated slides and stored at $-20^{\circ} \mathrm{C}$ until immunostaining. For short-term analysis (14 days after crush), axons were labeled by immunostaining for GAP43 (1:50; Santa Cruz Biotechnology) for $18 \mathrm{~h}$ followed by a secondary Cy3conjugated antibody (1:1000; Jackson ImmunoResearch) in $0.1 \%$ PBST. For long-term analysis (120 days after crush), axons were anterograde-labeled with Alexa 555conjugated cholera toxin beta subunit (CTB; Life 
Technologies, $3 \mu \mathrm{L}, 1: 1$ in sterile PBS) injected into the vitreous body 2 days before perfusion, according to protocols previously described [47].

Axons extending beyond the lesion site were counted at different distances from the injury site by a masked observer using a $\times 40 / 0.75$ Plan-Neofluar objective (Axiovert $200 \mathrm{M}$ microscope, Zeiss, Oberkochen, Germany). The total number of axons was estimated by the formula described by Leon and coworkers [48]. At least 3 sections were quantified for each animal. Statistical analysis was performed using two-way ANOVA for axonal extension analysis, in GraphPad Prism 6.

\section{Light deprivation and stimulation for NGFI-A quantification}

To investigate whether the regenerated axons observed in the hWJ-MSCs-treated animals established synapses with SC neurons, we analyzed the expression of nerve growth factor-induced gene A (NGFI-A), a transcription factor expressed in SC neurons after visual stimulation [49]. To eliminate responses induced by the intact eye, the right optic nerve was transected 7 days before this experiment. The animals were anesthetized as described above, and the right optic nerve was cut with scissors.

To assess NGFI-A expression in the SC, the animals were light-deprived for $24 \mathrm{~h}$, followed by $2 \mathrm{~h}$ of light stimulation before perfusion with paraformaldehyde. Tissue was prepared as described above. Brain sections were washed with PBST-0.1 blocked with normal goat serum and incubated overnight with a specific antibody against NGFI-A (anti-Egr1, 1:400, rabbit, Santa Cruz Biotechnology), followed by incubation with Alexa 488conjugated goat anti-rabbit IgG antibody (1:1000) and ToPro-3 (1:1000; Life Technologies) and mounted with PPD. Images were acquired using a confocal microscope (Zeiss LSM 510 Meta), using a $\times 20 / 0.5$ PlanNEOFLUAR objective. Three brain sections on the rostro-caudal axis were chosen per animal, to obtain three images each of $0.135 \mathrm{~mm}^{2}$ from medial to lateral, covering the superficial layers of the SC. The number of NGFI- $A^{+}$cells was counted manually by a masked observer, normalized by the image area, and the data were separated into ipsilateral and contralateral sides of SC. Statistical analysis was performed using an unpaired parametric $t$ test in GraphPad Prism 6 (GraphPad Software Inc., San Diego, CA, USA).

\section{Results}

hWJ-MSC treatment protects RGCs after optic nerve crush Rodent MSCs have been reported to protect RGCs after optic nerve injuries [7]. However, validating the neuroprotective potential of human-derived MSCs is necessary before proceeding to clinical trials. Here, we found that 14 days after optic nerve crush and vehicle injection, the number of $\mathrm{Tuj}^{+}$retinal neurons was dramatically reduced to $15.39 \%$ of the number in the control retina $\left(1142 \pm 49.46\right.$ Tuj $^{+}$cells $/ \mathrm{mm}^{2}$ in control retinas; $117.8 \pm 22.34$ Tuj $1^{+}$cells $/ \mathrm{mm}^{2}$ in the vehicle group; Fig. $1 \mathrm{~A}, \mathrm{~B}, \mathrm{~F})$, consistent with previous studies $[5,6,8$, $31,50]$. Treatment with hWJ-MSCs significantly increased RGC survival to $37.62 \%$ of the number in the control retina $\left(429 \pm 33.01 \mathrm{Tuj} 1^{+}\right.$cells $/ \mathrm{mm}^{2}$ in the hWJMSC group; Fig. 1C, F). Since clinical protocols require that cell therapy be performed in xeno-free conditions [51], we evaluated if serum deprivation affects the neuroprotective potential of hWJ-MSCs. We found that there was no statistically significant effect of the presence or absence of serum on the neuroprotective effect, although the mean number of surviving RGCs treated with $\mathrm{hWJ}$-MSCs cultured in the presence of serum was higher compared to SD-hWJ-MSCs $\left(338.5 \pm 25.00\right.$ Tuj $1^{+}$ cells $/ \mathrm{mm}^{2}$; Fig. 1D, F). For consistency, we used cells cultured in the presence of serum in the remaining experiments. In addition, we tested if the therapeutic effect of hWJ-MSCs could be reproduced by injecting only the EVs derived from these cells. The number of surviving RGCs 14 days after crush and treatment with EVs $\left(188.4 \pm 27.11 \mathrm{Tuj}^{+}\right.$cells $\left./ \mathrm{mm}^{2}\right)$ was similar to the vehicle-treated group, suggesting that EVs alone did not reproduce the neuroprotective effects of hWJ-MSCs, at least in the dose used in this study (Fig. 1E, F).

\section{Treatment with hWJ-MSCs provided sustained RGC neuroprotection}

To best assess the therapeutic potential, we investigated if the neuroprotective effect of hWJ-MSCs was sustained for periods longer than 14 days. At 60 and 120 days after crush, the number of Tuj $1^{+}$cells decreased to $10 \%$ and $5 \%$ of the control, respectively, in the vehicle-treated group $\left(117.3 \pm 28.94\right.$ Tuj1 $1^{+}$cells $/ \mathrm{mm}^{2}$; and $49.15 \pm 12.68$ Tuj $1^{+}$cells $/ \mathrm{mm}^{2}$; Fig. 2A-E). Notably, treatment with hWJ-MSCs led to a significant $\sim 2$-fold increase in the percentage of surviving RGCs at both time points $\left(242.2 \pm 42.16 \mathrm{Tuj} 1^{+}\right.$cells $/ \mathrm{mm}^{2}$ or $22.63 \%$ survival at 60 days; and $107.6 \pm 15.59 \mathrm{Tuj} 1^{+}$cells $/ \mathrm{mm}^{2}$ or $10.36 \%$ survival 120 days after crush; Fig. 2A-E).

\section{Treatment with hWJ-MSCs protects different subpopulations of RGCs}

RGCs can differ according to their morphology, gene expression profile and electrophysiological properties [52]. Previous studies from our group showed that $10 \%$ of the total Tuj $1^{+}$cell population in rat retinas have large cell bodies (more than $150 \mu \mathrm{m}^{2}$ of the soma size), cytoplasm densely labeled with Tuj 1 and extensively arborized dendrites, and express osteopontin [31], which is consistent with the mouse $\alpha$ RGC subtype that has been reported to be more resilient to injury [53, 54]. We investigated 

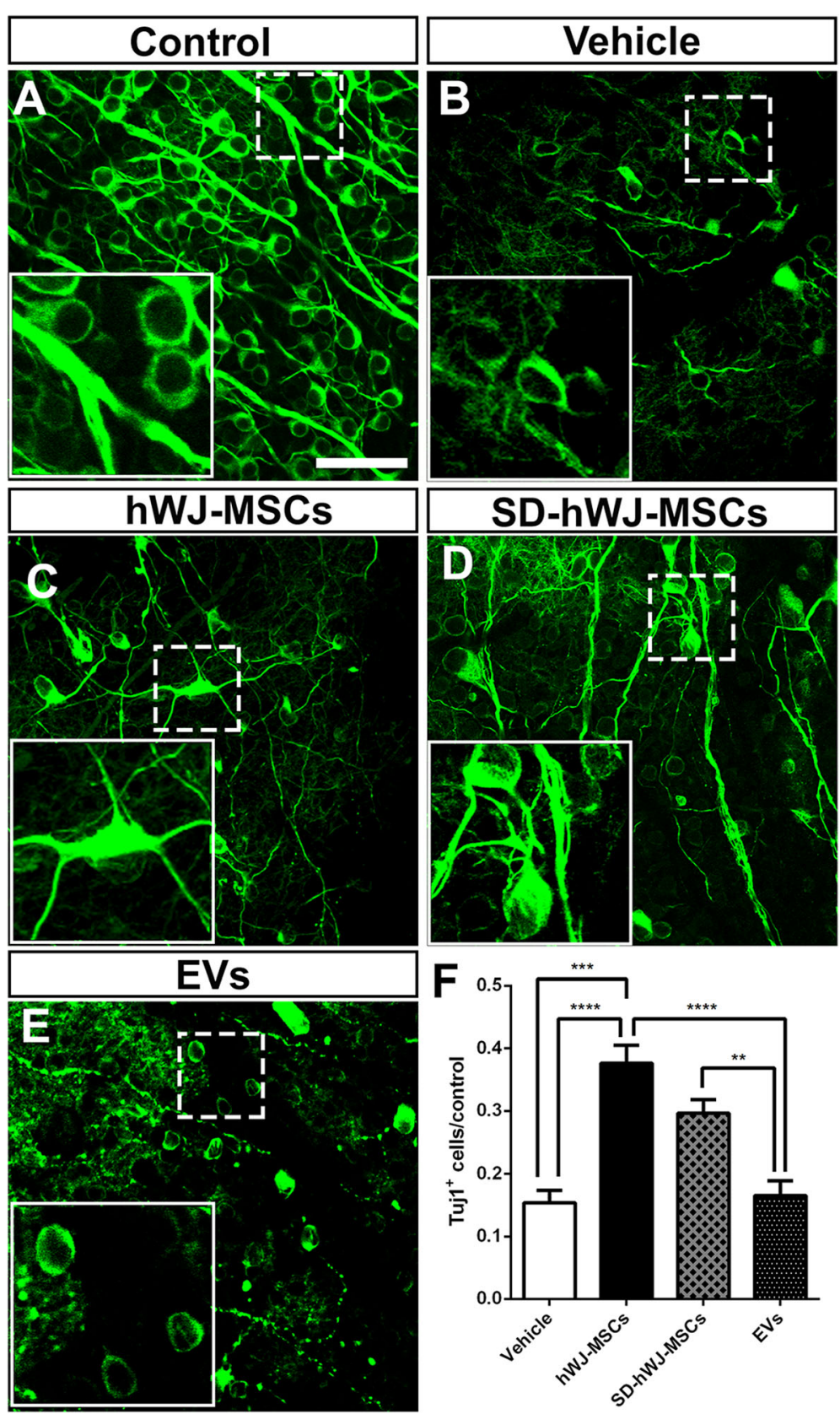

Fig. 1 Survival of RGCs 14 days after crush and hWJ-MSC-based treatments. a-e Confocal images of an optical slice of whole-mounted retinas labeled for Tuj1, 14 days after crush and injection of vehicle, hWJ-MSCs, SD-hWJ-MSCs (after $24 \mathrm{~h}$ of fetal bovine serum deprivation), or EVs. Inset in the lower left corner of each image shows higher magnification of the dashed square. $\mathbf{f}$ Graph representing the number of RGCs of each experimental group normalized by control retinas. Mean \pm SEM. One-way ANOVA with Tukey post-test, ${ }^{*} P<0.5,{ }^{* *} P<0.1$, ${ }^{* *} P<0.001$, ${ }^{* * *} P<0.0001$. Scale bars $50 \mu \mathrm{m}$ for images and $21 \mu \mathrm{m}$ for insets

whether treatment with hWJ-MSCs preferentially protected large RGCs at 60 and 120 days after optic nerve crush.

At 60 days after crush, we observed a very small population of Tuj $1^{+}$cells with soma size larger than $150 \mu \mathrm{m}^{2}$ in the vehicle group $\left(141.6 \pm 26.5 \mathrm{Tuj}^{+}\right.$cells/retina, or $2.35 \%$ of the surviving RGCs). However, treatment with
hWJ-MSCs protected significantly more large Tuj $1^{+}$cells $\left(1266 \pm 386.8 \mathrm{Tuj}^{+}{ }^{+}\right.$cells/retina, or $11.02 \%$ of the surviving Tuj $1^{+}$cells) than in the vehicle group $(P<0.05)$. At 120 days after crush, we still found a significant difference in the number of large Tuj $1^{+}$cells after treatment with hWJ-MSCs $\left(1648.65 \pm 395\right.$ Tuj $^{+}$cells/retina, or $24.05 \%$ of surviving Tuj $1^{+}$cells) in comparison to the 


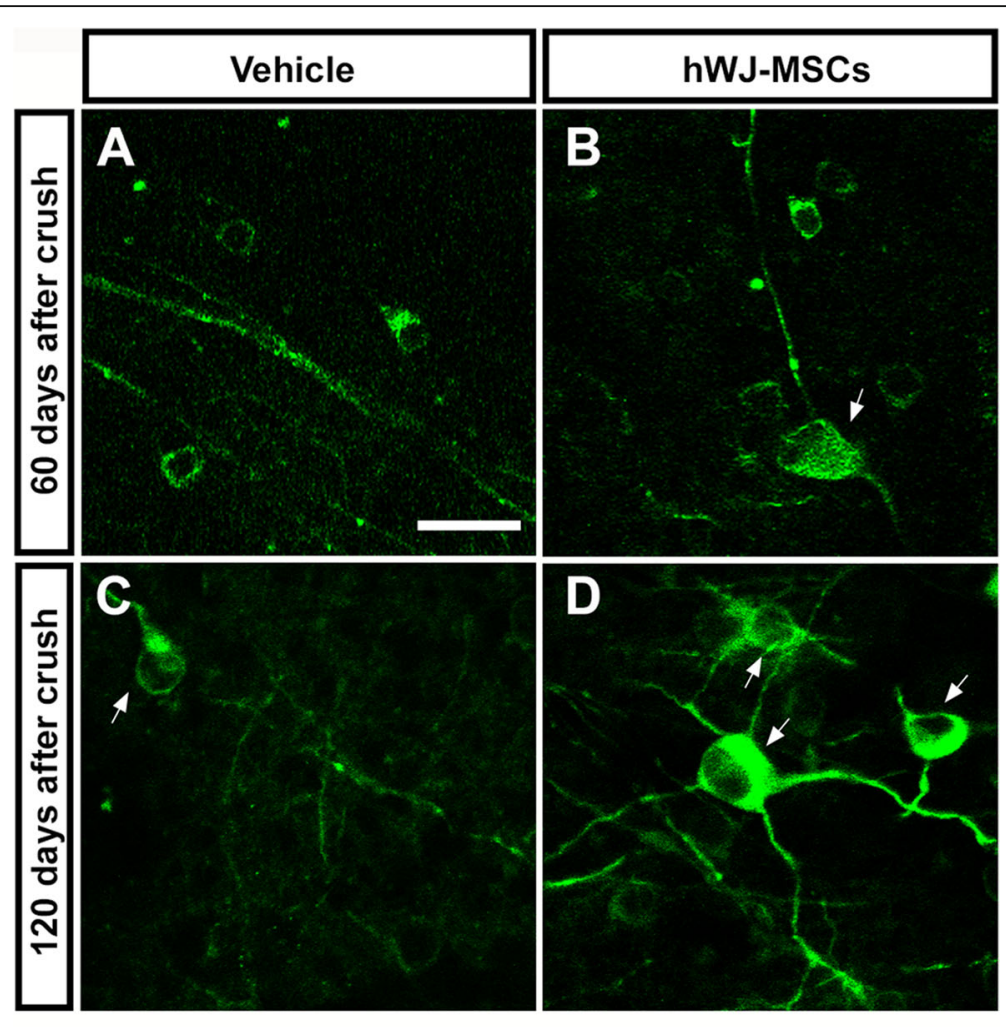

E
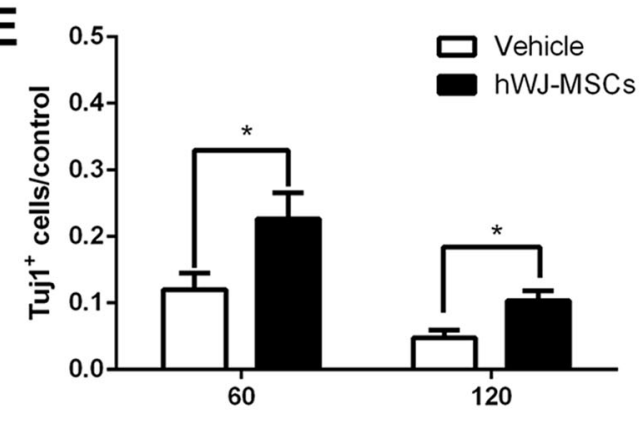

Days after crush

$\mathbf{F}$

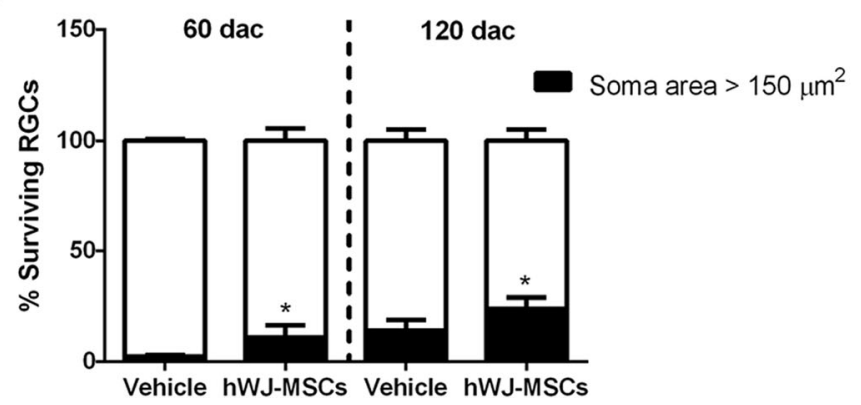

Fig. 2 Long-term neuroprotective effect of hWJ-MSCs on RGCs. High magnification of confocal images of retinas immunostained for Tuj1 (a-d) 60 and 120 days after crush and injection of vehicle ( $\mathbf{a}$ and $\mathbf{b}$ ) or hWJ-MSCs (c and $\mathbf{d}$ ). Arrows indicate RGCs with soma larger than $150 \mu \mathrm{m}^{2}$. e Number of RGCs in the ipsilateral retina normalized by the contralateral eye. f Percentage of surviving RGCs with soma larger than $150 \mu m^{2}$ (black bars) at 60 and 120 days after crush and injection of vehicle or hWJ-MSCs. Mean \pm SEM. Unpaired parametric $t$ test, ${ }^{*} P<0.5$. Scale bar $25 \mu \mathrm{m}$ 
vehicle group $\left(394.8 \pm 139.1 \mathrm{Tuj}^{+}\right.$cells/retina, or $14.14 \%$ of surviving Tuj $1^{+}$cells). The number of Tuj $1^{+}$ cells smaller than $150 \mu \mathrm{m}^{2}$ did not differ significantly between the vehicle and hWJ-MSCs, either 60 or 120 days after crush. Moreover, the number of smaller Tuj $1^{+}$cells decreased between 60 and 120 days in both groups, suggesting that they continued to degenerate. Interestingly, between 60 and 120 days after crush, in the hWJ-MSCtreated group, there was no significant decrease in RGCs larger than $150 \mu \mathrm{m}^{2}$, suggesting that the cell therapy preferentially sustained the survival of large Tuj ${ }^{+}$cells, including the $\alpha$ RGCs. In addition to being more resistant to injury, $\alpha$ RGCs are known to extend axons after crush, mainly after mTOR pathway activation, and to re-grow axonal projections up to the SC [53].

\section{Treatment with hWJ-MSCs promotes RGC axonal regeneration to brain targets}

Because hWJ-MSCs provided a long-term neuroprotective effect, favoring survival of large RGCs, we investigated if the hWJ-MSC treatment promoted axonal outgrowth beyond the lesion site. For short-term analysis (14 days after crush), axonal regeneration was evaluated using the expression of GAP43, a protein expressed only by neurons during the axon growth process [15] (Fig. 3). Optic nerve crush led to GAP43 expression as observed in the vehicle group, yet we found only a few axons crossing the lesion site (Fig. 3A, C). Notably, the hWJ-MSC treatment increased the number of $\mathrm{GAP} 3^{+}$axons traveling over longer distances beyond the lesion site (Fig. 3B, C).

For long-term analysis, axons were anterogradely traced by intraocular injection of CTB. In the vehicle group, only a few axons were found up to $2 \mathrm{~mm}$ beyond the lesion site at 120 days after the crush (Fig. 4A, C). Treatment with hWJ-MSCs dramatically increased the number of labeled axons extending beyond the injury site at all time points compared to the vehicle, and 5 of 11 animals showed axons extending to the optic chiasm (approximately $6.5 \mathrm{~mm}$ from the lesion site, Fig. 4B, C).

We also investigated whether these extending axons were able to reach the visual targets in the brain, by evaluation of coronal sections of the dLGN and SC (Fig. 5). Notably, we found regenerated RGC axons labeled with CTB in the dLGN ( 2 of 11 animals) and in the SC (4 of 11) at 120 days after optic nerve crush in

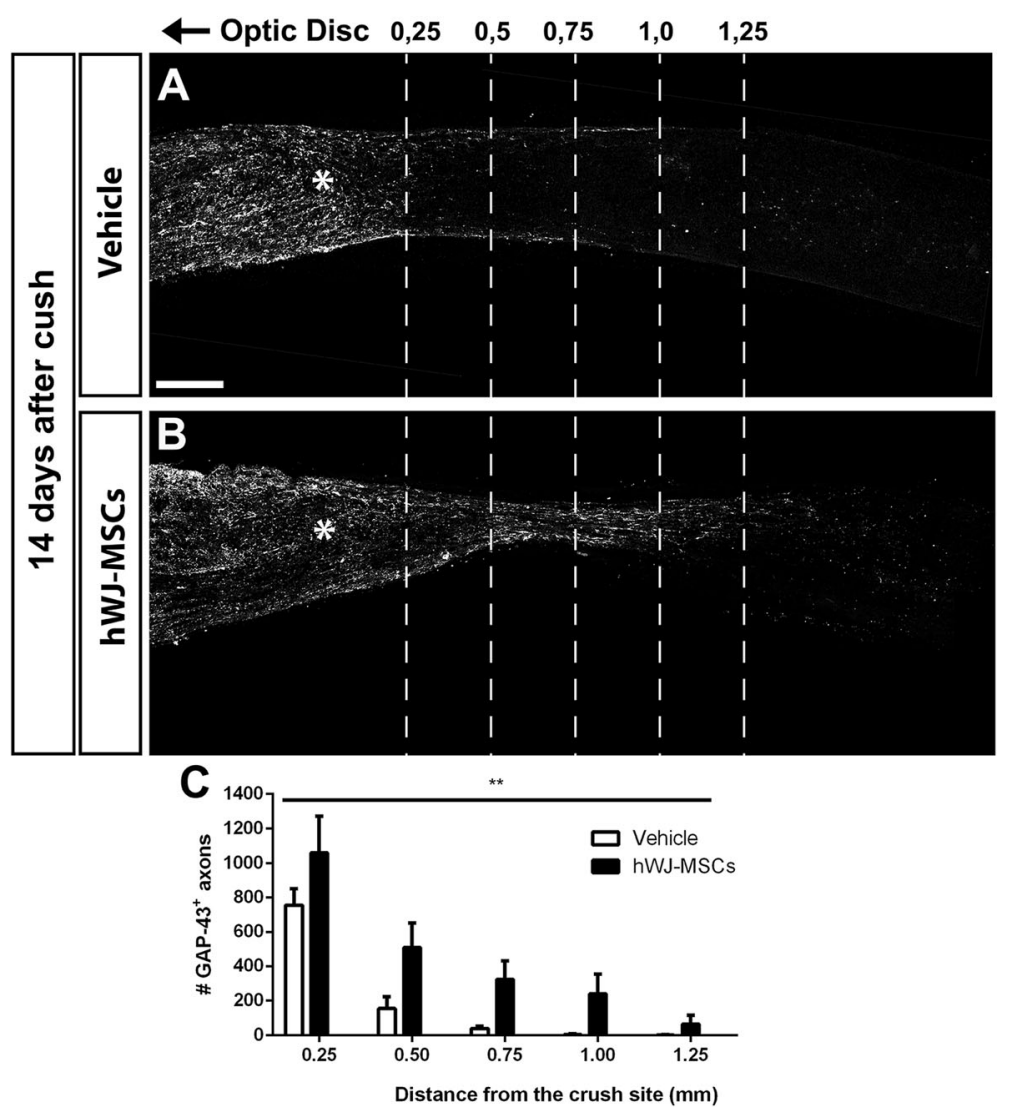

Fig. 3 hWJ-MSC treatment promotes optic nerve regeneration. Photomontage of optic nerve sections immunostained for GAP-43 14 days after lesion and treatment with vehicle (a) or hWJ-MSCS (b). c Graph representing the mean \pm SEM of axons at respective distances from the crush site in vehicle or hWJ-MSC-treated groups. Two-way ANOVA, ${ }^{* *} P<0.01$. Scale bar $200 \mu \mathrm{m}$ 

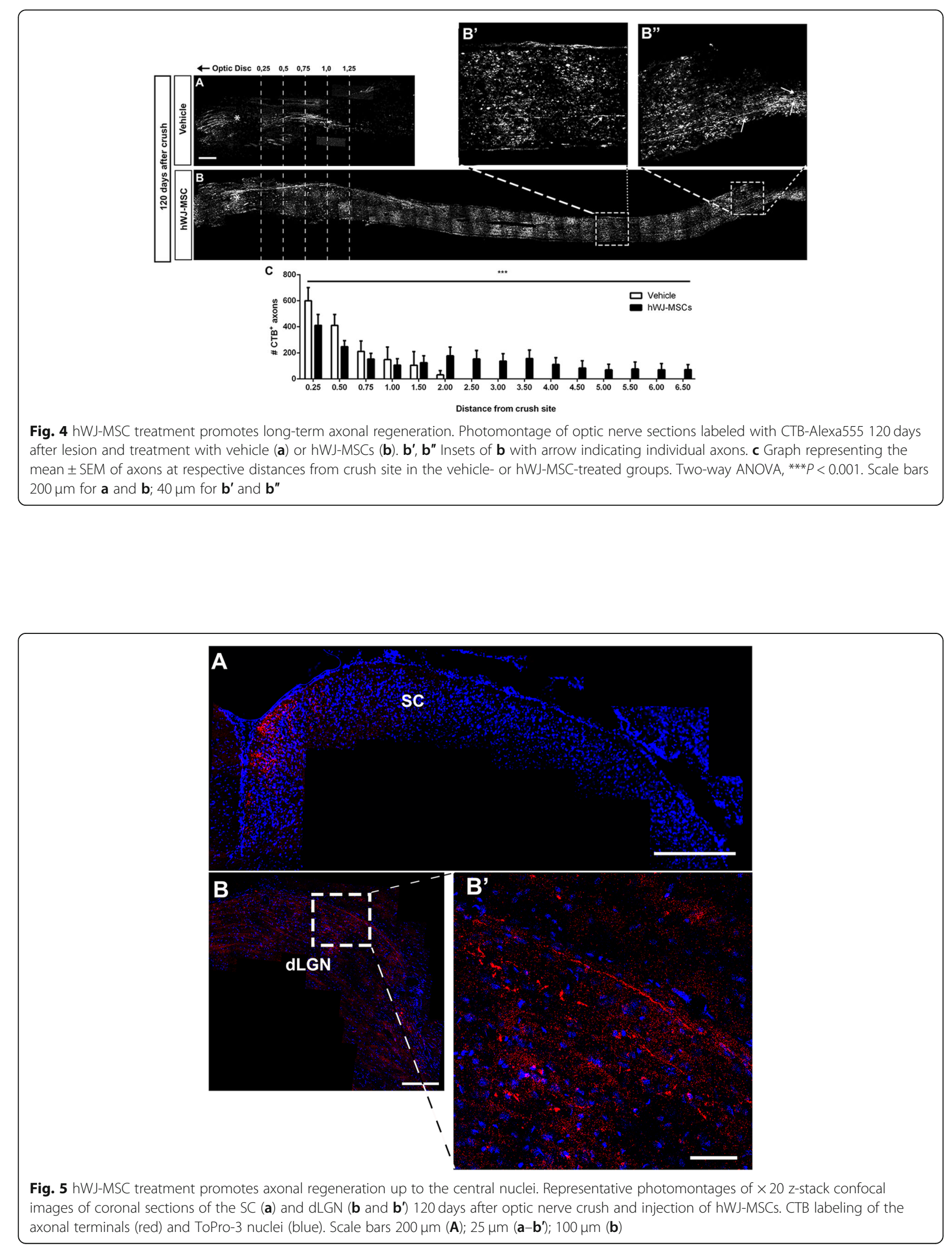
animals treated with hWJ-MSCs (Fig. 5), suggesting that some axons could reach central targets. No CTB staining was found in brain sections of the vehicle group $(N=6)$, indicating absence of target reconnection in these animals. Therefore, treatment with hWJ-MSCs induced a marked RGC axon regrowth up to central targets.

\section{Treatment with hWJ-MSCs increases synaptic connection in the SC}

To investigate if RGC axon regeneration and reinnervation led to formation of new synapses within brain targets, we analyzed the expression of light-induced NGFI$A$ in the SC. NGFI- $A$ is an immediate early gene correlated with plasticity processes during development or after lesions [49, 55, 56]. NGFI- $A$ expression is almost completely abolished in the SC after dark adaptation, and is upregulated after light exposure, in a mechanism dependent on glutamate released by retinal terminals binding to NMDA receptors in collicular neurons [49]. To investigate whether the regenerating axons reconnected to SC neurons, we quantified the number of cells expressing NGFI-A after dark adaptation and light stimulation. In the vehicle group, only a few NGFI-A expressing cells were found in both ipsi- and contralateral SC $\left(44.35 \pm 6.15\right.$ and $93 \pm 16.23 N G F I-A^{+}$cells $/ \mathrm{mm}^{2}$, respectively; Fig. $6 \mathrm{~A}, \mathrm{~B}, \mathrm{E})$. Since the right optic nerve was sectioned, and no axons were found beyond the lesion site in the left nerve, the NGFI-A expression in SC of the vehicle group was likely due to a basal expression of this factor. Treatment with hWJ-MSCs significantly increased the number of NFGI-A-positive cells both in the contralateral and ipsilateral $\mathrm{SC}$, compared to the vehicle (77.52 \pm 11.96 and $186.9 \pm 14.34 N G F I-A^{+}$cells $/ \mathrm{mm}^{2}$, respectively; Fig. 6C, D, E), consistent with target reinnervation and synapse formation. This result suggests that, in addition to the neuroprotective and pro-regenerative stimulation of RGC axons up to the central targets in the brain, hWJ-MSCs transplantation promoted axontarget reconnection through glutamatergic synapses. However, despite this long-distance axonal regeneration up to visual targets (the dLGN and SC) and synapse reconnection, we have not observed functional recovery of visual behaviors (optokinetic or looming reflexes and dark/light preference test, data not shown).

\section{Discussion}

Loss of RGCs is irreversible and can lead to partial or complete blindness. To date, no clinical therapy is available to protect RGCs and/or promote their axonal regrowth and target reconnection in the visual pathway. We investigated the neuroprotective and regenerative effects of intravitreal transplantation of hWJ-MSCs after optic nerve crush, which is a traumatic axonal injury leading to severe loss of RGCs $[6,8,30,50]$. Treatment with hWJ-MSCs resulted in sustained survival of RGCs, marked long-distance axonal regeneration up to central targets, and partial recovery of the synaptic function.

MSCs can be obtained from several sources, including the human umbilical cord. This source is of particular interest because it is feasible to obtain and has advantageous biological properties. For instance, since the umbilical cord is obtained from newborns, it should have fewer epigenetic alterations than adult tissues [36], providing more consistent results when used for therapeutic purposes. Furthermore, the umbilical cord is a tissue necessarily collected at childbirth that is usually discarded and therefore does not require invasive procedures [36]. Compared to MSCs from other sources, for instance bone marrow, hWJ-MSCs can provide major trophic support and produce cytokines, including IL6, IL8, BDNF, LIF, NT-3, TGF $\beta 2$, and FGF2 [37, 57]. Importantly, MSCs from multiple sources do not show potential to generate tumors and teratoma, and compared to MSCs derived from human umbilical cord blood (hUCB-MSC), hWJ-MSCs express a wider range of tumor suppressor factors [37].

MSCs can be delivery through several routes. Here, we used the intravitreal approach, which has been shown to be neuroprotective for RGCs in several pre-clinical studies [1-6]. However, a few clinical studies using the route reported adverse effects [7, 8]. On the other hand, a combination of intravitreal, retrobulbar, subtenon, and intravenous injection of BMMSCs has been used in other studies with good safety and efficacy results [914]. Therefore, it is important to explore and/or combine other delivery routes to optimize cell therapies for retinal and optic nerve injuries. Both subtenon and retrobulbar injections are periocular routes that can be used to deliver molecules to the posterior segment of the eye and avoid the adverse effects of intravitreal injection [15]. Recently, a phase-3 clinical trial showed that a subtenon injection of hWJ-MSCs results in good outcomes for patients with retinitis pigmentosa [16]. This approach should be investigated in the optic nerve injury model and compared with other routes. In addition, a more direct approach such as a direct injection into the optic nerve should also be explored as recently described by Mesentier-Louro and colleges [17, 31]. In summary, safety and efficacy of different routes can be assessed in pre-clinical models in order to subsidize better clinical studies.

The effects of MSCs have been attributed to paracrine mechanisms rather than to differentiation into neural cells or integration into the retina [58]. Both direct release and/or delivery of EVs carrying molecules that act to promote survival or growth of the target cell have been suggested $[39,59]$. In our experiments, we found that injection of hWJ-MSC-derived EVs did not protect 

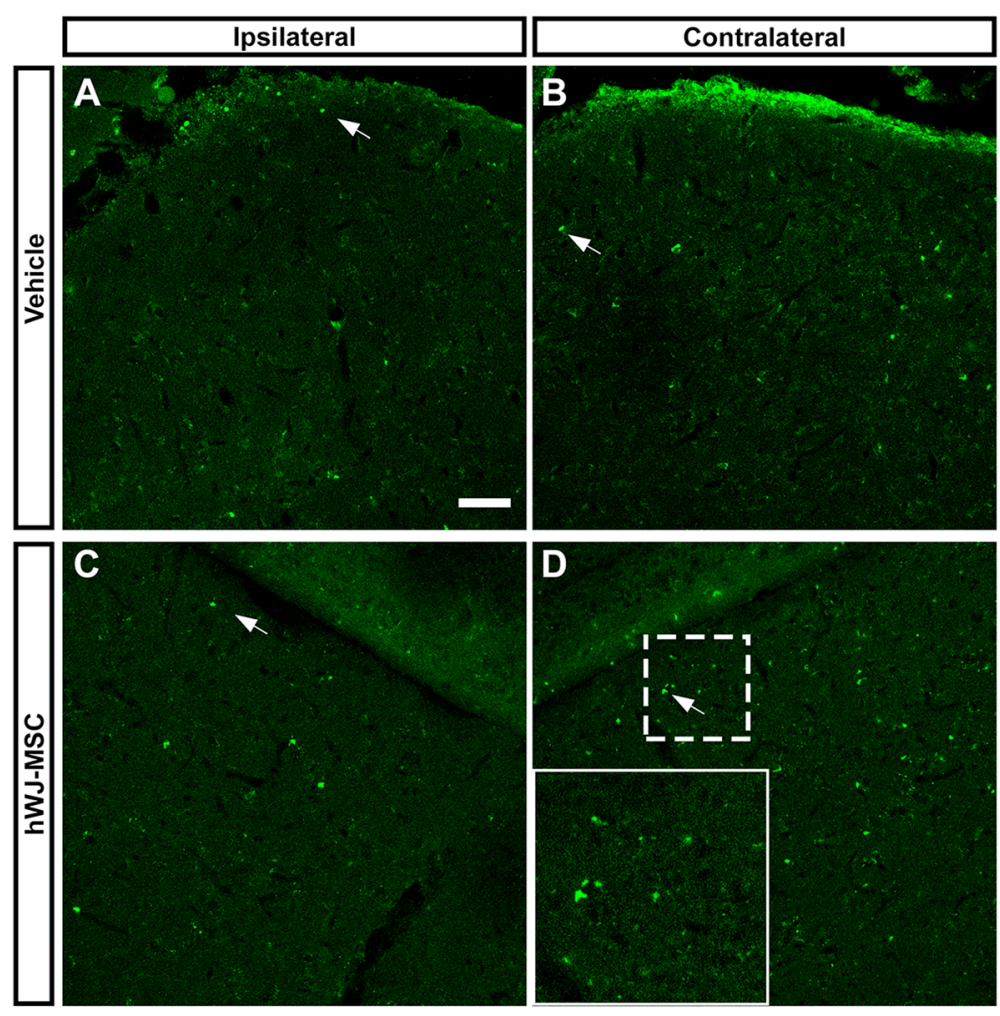

\section{E}

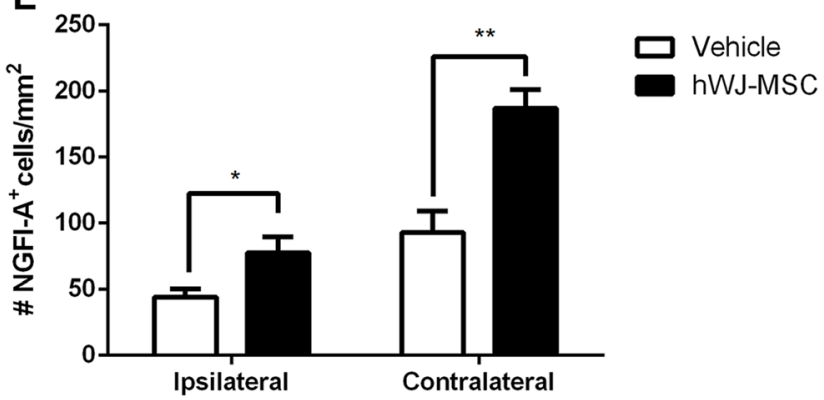

Fig. 6 RGC terminals activate SC neurons. Images of $\times 20$ z-stack confocal images. NGFI-A immunolabeling to identify activation of SC cells after light exposure in coronal section of ipsi- and contralateral SC 120 days after optic nerve crush and treatment with vehicle (a, b) or hWJ-MSCs $(\mathbf{c}, \mathbf{d})$. Inset in $\mathbf{d}$ shows higher magnification of the dashed square. e Quantification of the number of cells expressing NGFI-A per mm ${ }^{2}$ in each group \pm SEM. Unpaired parametric $t$ test, ${ }^{*} P<0.05$, ${ }^{* *} P<0.01$. Scale bars $50 \mu \mathrm{m}$ for images $\mathbf{a}-\mathbf{d} ; 23 \mu \mathrm{m}$ for inset

RGCs. We injected a single dose of EVs released by the $\mathrm{hWJ}$-MSCs over a period of $24 \mathrm{~h}$ in vitro, which could explain the negative results. MSCs survive in the vitreous body for several weeks and continuously release EVs. In addition, MSCs change the content of EVs released according to changes in the host tissue. All these factors could explain the absence of effects of EVs in our experiments and the positive results in other studies [60]. At this point, it is not possible to exclude the possibility that the beneficial effects of hWJ-MSC therapies are mediated by VE release. We also found that hWJMSCs exert neuroprotective effects independently of the presence of serum in the medium. Indeed, although MSC gene expression was altered after serum deprivation, this was not sufficient to interfere with their surface antigen expression, multipotentiality, and immunosuppressive potential [61]. These results support a neuroprotective effect of hWJ-MSCs cultured in xenofree conditions, which has important implications for their safe clinical use.

Further, we found that treatment with hWJ-MSCs preferentially increased the survival of large-sized RGCs. While smaller RGCs continued to decay after crush, the number of larger RGCs was sustained over time in the hWJ-MSC-treated group compared to the vehicletreated group. It has been estimated that more than 46 different subtypes of RGCs are found in the rodent retina, differing in their morphology, localization, gene 
expression, and physiological properties [54]. As Tuj $1^{+}$ cells with more than $150 \mu \mathrm{m}^{2}$ area comprise mostly the $\alpha$ RGCs [31], and this RGC type is known to project axons to the SC [62], it is possible that the treatment selectively targeted $\alpha$ RGCs. Indeed, it has been shown that $\alpha R G C s$ regenerate their axons after activation of the mTOR pathway and are among the most resistant RGC subtypes after optic nerve lesion [53, 54, 62].

In addition to the survival of RGCs, we also found marked axonal regeneration in animals treated with hWJ-MSCs. While none of the animals in the vehicle group had axons regenerating farther than $2 \mathrm{~mm}$ from the lesion site, we observed staining for CTB in the optic chiasm of 5 out of 11 animals, and in the SC of 4 out of 11 animals in the hWJ-MSC-treated group, at 120 days after crush, showing that the treatment promoted the regeneration of RGC axons to these targets. Notably, we demonstrated evidence of the reconnection of RGCs with the SC through the re-establishment of active glutamatergic synapses, as shown by increased NGFI-A expression. The small number of NGFI-A expressing cells in SC of both the ipsi- and contralateral sides in the vehicle group was likely a result of a basal expression of $N G F I-A$, and all animals were subjected to transection of the non-crushed nerve 7 days before the lightstimulation experiment to eliminate a light-response from the uncrushed visual pathway. In addition, some evidence indicates that the absence of vision induces plasticity in subcortical visual areas, which can receive stimulus from areas related to hearing [63].

As well as the allogenic therapy with bone marrowderived MSCs (BM-MSCs) [6, 31], treatment with hWJMSCs provided a long-term effect capable of delaying the death of RGCs and promote axonal outgrowth for long distances in the optic nerve, leading to target reconnection in nearly half of the animals that were treated. Although several studies have described therapeutic effects of human MSCs after optic nerve lesion $[47,58,64,65]$, none has investigated their long-term effect or demonstrated target reconnection. For example, our results differ from those of other studies using hUCB-MSCs and hWJ-MSCs, which found a loss of the neuroprotective effect after 28 days $[66,67]$. The sustained neuroprotective and pro-regenerative effects that we observed could be explained by the dose used here, which was 25 times higher than that used by Millán-Rivero [67], revealing the importance of dose studies in the pre-clinical setting.

To the best of our knowledge, only a few approaches have been able to promote axonal regeneration to brain targets after optic nerve injury. Our group previously demonstrated that RGC axons can regenerate to the SC after therapy with BMMCs in an optic nerve crush model [8]. Umbilical cord-derived MSCs have been shown to promote axonal regeneration and protect RGCs in an optic tract lesion model [68]. It has also been shown that in mice subjected to optic-nerve lesion, the induction of inflammation combined with cAMP injection and deletion of PTEN induces axons to regenerate to central targets [27]. It has been reported that activation of the mTOR pathway together with visual simulation to the injured eye leads to a striking regeneration, with axons extending to the suprachiasmatic nucleus, dLGN, pretectal nucleus, medial terminal nucleus, and SC [62]. This visual stimulation could be used in combination with the treatment with hWJ-MSCs described here to amplify the outgrowth capability of RGCs.

Axonal regeneration to visual targets is a challenge for optic nerve treatments, and many efforts have been made to develop regenerative strategies. The present study is the first to demonstrate a sustained protective and regenerative effect on rat adult axons after therapy with human-derived MSCs in an optic nerve lesion model. These findings highlight the effectiveness of the cell therapy using an easily obtained source of human MSCs for future clinical studies. However, many preclinical studies are still needed before translational studies can be performed.

\section{Conclusions}

This study presents evidence of positive effects of cell therapy using hWJ-MSCs for optic nerve injury. We have shown the potential of allogenic transplantation of MSCs to protect and promote RGC axon outgrowth in the animal model used here and for the first time have shown a long-term effect of human-derived MSCs. Even 120 days after injury, the hWJ-MSC-treated group presents a higher number of RGCs and their axons reached and make synapses with the SC. This finding is useful for the development of therapeutic strategies, since the umbilical cord is a reliable source of MSCs, insofar as it is a highly available tissue that is usually discarded and can be collected without invasive procedures. Although the results are promising, additional data about cell therapy with hWJ-MSCs are needed to understand the neuroprotective and regenerative effects. Further steps should be taken to understand the cellular and molecular mechanisms by which hWJ-MSCs exert their effect and to develop combined approaches to enhance the therapeutic effect.

\section{Abbreviations}

BMMCs: Bone marrow-derived mononuclear cells; BM-MSCs: Bone marrowderived MSCs; CTB: Cholera toxin beta subunit; DMEM F-12: Dulbecco's

modified Eagle's medium F-12; EVs: Extracellular vesicles; dLGN: Dorsal lateral geniculate nucleus; FBS: Fetal bovine serum; GAP43: Growth-associated protein 43; hUCB-MSCs: Human umbilical cord blood-derived MSCs; hWJMSCs: Human umbilical Wharton's jelly-derived MSCs; MSCs: Mesenchymal stem cells; NGFI-A: Nerve growth factor-induced gene A; OCT: Optimal 
cutting temperature; PBS: Phosphate-buffered saline; PBST: PBS with Triton-X; PPD: p-Phenylenediamine; Pten: Phosphatase and tensin homolog; RGCS: Retinal ganglion cells; SC: Superior colliculus; SD-: Serum deprivation; Socs3: Suppressor of cytokine signaling 3

\section{Acknowledgements}

The authors thank Felipe Marins for technical assistance.

\section{Significance statement}

The visual system is widely used as model to study the limited regenerative potential of the central nervous system. No treatment is presently available to prevent partial vision loss and blindness. Therapies with mesenchymal stem cells from different sources have been used experimentally to increase neuron survival and regeneration. In the present study, we show that a treatment with human cells resulted in long-term neuroprotection and regeneration for central targets in an optic-nerve injury model. The present report provides evidence for treatment with mesenchymal stem cells obtained from the umbilical cord, a reliable source of human cells.

\section{Authors' contributions}

Almir Jordão da Silva-Junior (A.J. Silva-Junior) jordao.a@biof.ufri.br: conception; design of the study; acquisition, analysis, interpretation of data; drafted the manuscript; approved the submitted version; agreed both to be personally accountable for the author's own contributions and to ensure that questions related to the accuracy or integrity of any part of the study are appropriately investigated and resolved. Louise Alessandra Mesentier-Louro (L.A. Mesentier-Louro) louro@stanford.edu: acquisition, analysis, interpretation of data; approved the submitted version; agreed both to be personally accountable for the author's own contributions and to ensure that questions related to the accuracy or integrity of any part of the study are appropriately investigated and resolved. Gabriel Nascimento-dos-Santos (G. Nascimentodos-Santos) gabriel.nascimento@biof.ufrj.br: acquisition, analysis, interpretation of data; approved the submitted version; agreed both to be personally accountable for the author's own contributions and to ensure that questions related to the accuracy or integrity of any part of the study are appropriately investigated and resolved. Leandro Coelho Teixeira-Pinheiro (L.C. TeixeiraPinheiro) leandrocoelho@biof.ufrj.br: acquisition, analysis, interpretation of data; approved the submitted version; agreed both to be personally accountable for the author's own contributions and to ensure that questions related to the accuracy or integrity of any part of the study are appropriately investigated and resolved. Juliana F. Vasques (J.F. Vasques) julianavasques@biof.ufrj.br: acquisition, analysis, interpretation of data; approved the submitted version; agreed both to be personally accountable for the author's own contributions and to ensure that questions related to the accuracy or integrity of any part of the study are appropriately investigated and resolved. Luiza Chimeli-Ormonde (L. Chimeli-Ormonde) luizaormonde@biof.ufrj.br: acquisition, analysis, interpretation of data; approved the submitted version; agreed both to be personally accountable for the author's own contributions and to ensure that questions related to the accuracy or integrity of any part of the study are appropriately investigated and resolved. Victor Bodart-Santos (V. Bodart-Santos) victorbodart@gmail.com: acquisition, analysis of data; approved the submitted version; agreed both to be personally accountable for the author's own contributions and to ensure that questions related to the accuracy or integrity of any part of the study are appropriately investigated and resolved. Luiza Rachel Pinheiro de Carvalho (L.R.P. Carvalho) luizarachel@gmail.com: acquisition, analysis of data; approved the submitted version; agreed both to be personally accountable for the author's own contributions and to ensure that questions related to the accuracy or integrity of any part of the study are appropriately investigated and resolved. Marcelo Felippe Santiago (M.F. Santiago) marcelo.santiago@biof.ufrj.br: conception, design of the study, approved the submitted version; agreed both to be personally accountable for the author's own contributions and to ensure that questions related to the accuracy or integrity of any part of the study are appropriately investigated and resolved. Rosalia Mendez-Otero (R. Mendez-Otero) rmotero@biof.ufrj.br: Conception, design of the study, approved the submitted version; agreed both to be personally accountable for the author's own contributions and to ensure that questions related to the accuracy or integrity of any part of the study.

\section{Funding}

This study was supported by grants and fellowships from the Departamento de Ciência e Tecnologia (DECIT/MS) do Ministério da Saúde, Conselho Nacional de Desenvolvimento Científico e Tecnológico (CNPq), Instituto Nacional de Ciência e Tecnologia em Medicina Regenerativa, Fundação de Amparo à Pesquisa do Estado do Rio de Janeiro (FAPERJ), and Coordenação de Pessoal de Ensino Superior (CAPES/MEC).

\section{Availability of data and materials}

The datasets used and/or analyzed during the current study are available from the corresponding author on reasonable request.

\section{Ethics approval and consent to participate}

All procedures involving human-derived materials were approved by and followed the guidelines of the Institutional Human Ethical and Research Committee of the Clementino Fraga Filho Hospital of the Federal University of Rio de Janeiro. Experiments with animals followed the National Institutes of Health guidelines and were approved and monitored by the Institutional Animal Care and Use Committee of the Federal University of Rio de Janeiro.

\section{Consent for publication}

Not applicable.

\section{Competing interests}

The authors declare that they have no competing interests.

\section{Author details}

${ }^{1}$ Instituto de Biofísica Carlos Chagas Filho, Universidade Federal do Rio de Janeiro, Rio de Janeiro, RJ 21941-902, Brazil. ²Instituto Nacional de Ciência e Tecnologia em Medicina Regenerativa-REGENERE, Rio de Janeiro, RJ, Brazil.

${ }^{3}$ Rede NanoSaúde, Rio de Janeiro, RJ, Brazil. ${ }^{4}$ Department of Ophthalmology, Stanford University, Palo Alto, CA, USA.

Received: 22 November 2020 Accepted: 28 December 2020

Published online: 19 January 2021

\section{References}

1. Harvey AR, Hu Y, Leaver SG, Mellough CB, Park K, Verhaagen J, Plant GW, Cui Q. Gene therapy and transplantation in CNS repair: the visual system. Prog Retin Eye Res. 2006;25(5):449-89.

2. Isenmann S. Molecular determinants of retinal ganglion cell development, survival, and regeneration. Prog Retin Eye Res. 2003;22(4):483-543.

3. Almasieh M, Wilson AM, Morquette B, Cueva Vargas JL, Di Polo A. The molecular basis of retinal ganglion cell death in glaucoma. Prog Retin Eye Res. 2012;31(2):152-81.

4. Boia R, Ruzafa N, Aires ID, Pereiro X, Ambrosio AF, Vecino E, Santiago AR. Neuroprotective strategies for retinal ganglion cell degeneration: current status and challenges ahead. Int J Mol Sci. 2020:21(7):2262.

5. Levkovitch-Verbin H, Harris-Cerruti C, Groner Y, Wheeler LA, Schwartz M, Yoles E. RGC death in mice after optic nerve crush injury: oxidative stress and neuroprotection. Invest Ophthalmol Vis Sci. 2000;41(13):4169-74.

6. Mesentier-Louro LA, Zaverucha-do-Valle $C$, da Silva-Junior AJ, NascimentoDos-Santos G, Gubert F, de Figueiredo AB, Torres AL, Paredes BD, Teixeira C, Tovar-Moll F, et al. Distribution of mesenchymal stem cells and effects on neuronal survival and axon regeneration after optic nerve crush and cell therapy. PLoS One. 2014;9(10):e110722.

7. Mesentier-Louro LA, Zaverucha-do-Valle C, Rosado-de-Castro PH, Silva-Junior AJ, Pimentel-Coelho PM, Mendez-Otero R, Santiago MF. Bone marrowderived cells as a therapeutic approach to optic nerve diseases. Stem Cells Int. 2016;2016:5078619.

8. Zaverucha-do-Valle C, Gubert F, Bargas-Rega M, Coronel JL, Mesentier-Louro LA, Mencalha A, Abdelhay E, Santiago MF, Mendez-Otero R. Bone marrow mononuclear cells increase retinal ganglion cell survival and axon regeneration in the adult rat. Cell Transplant. 2011;20(3):391-406.

9. Goldberg JL, Espinosa JS, Xu Y, Davidson N, Kovacs GT, Barres BA. Retinal ganglion cells do not extend axons by default: promotion by neurotrophic signaling and electrical activity. Neuron. 2002;33(5):689-702.

10. Kurimoto T, Yin Y, Omura K, Gilbert HY, Kim D, Cen LP, Moko L, Kugler S, Benowitz LI. Long-distance axon regeneration in the mature optic nerve: contributions of oncomodulin, CAMP, and pten gene deletion. J Neurosci. 2010;30(46):15654-63. 
11. Park KK, Liu K, Hu Y, Smith PD, Wang C, Cai B, Xu B, Connolly L, Kramvis I, Sahin $\mathrm{M}$, et al. Promoting axon regeneration in the adult CNS by modulation of the PTEN/mTOR pathway. Science. 2008;322(5903):963-6.

12. Agudo M, Perez-Marin MC, Lonngren U, Sobrado P, Conesa A, Canovas I, Salinas-Navarro M, Miralles-Imperial J, Hallbook F, Vidal-Sanz M. Time course profiling of the retinal transcriptome after optic nerve transection and optic nerve crush. Mol Vis. 2008;14:1050-63.

13. Hunt $D$, Raivich $G$, Anderson PN. Activating transcription factor 3 and the nervous system. Front Mol Neurosci. 2012;5:7.

14. Guo Y, Cepurna WO, Dyck JA, Doser TA, Johnson EC, Morrison JC. Retinal cell responses to elevated intraocular pressure: a gene array comparison between the whole retina and retinal ganglion cell layer. Invest Ophthalmol Vis Sci. 2010;51(6):3003-18.

15. Holahan MR. A shift from a pivotal to supporting role for the growthassociated protein (GAP-43) in the coordination of axonal structural and functional plasticity. Front Cell Neurosci. 2017;11:266.

16. Benowitz LI, Popovich PG. Inflammation and axon regeneration. Curr Opin Neurol. 2011;24(6):577-83.

17. Qu J, Jakobs TC. The time course of gene expression during reactive gliosis in the optic nerve. PLoS One. 2013;8(6):e67094.

18. Rolls A, Shechter R, Schwartz M. The bright side of the glial scar in CNS repair. Nat Rev Neurosci. 2009;10(3):235-41.

19. Adams KL, Gallo V. The diversity and disparity of the glial scar. Nat Neurosci. 2017;21(1):9-15

20. Benowitz LI, He Z, Goldberg JL. Reaching the brain: advances in optic nerve regeneration. Exp Neurol. 2017;287(Pt 3):365-73.

21. Moore DL, Blackmore MG, Hu Y, Kaestner KH, Bixby JL, Lemmon VP, Goldberg JL. KLF family members regulate intrinsic axon regeneration ability. Science. 2009;326(5950):298-301.

22. Galvao J, Iwao K, Apara A, Wang Y, Ashouri M, Shah TN, Blackmore M, Kunzevitzky NJ, Moore DL, Goldberg JL. The Krüppel-like factor gene target Dusp14 regulates axon growth and regeneration. Invest Ophthalmol Vis Sci. 2018;59(7):2736-47.

23. Benowitz $L$, Yin $Y$. Rewiring the injured CNS: lessons from the optic nerve. Exp Neurol. 2008;209(2):389-98

24. Shah SH, Goldberg JL. The role of axon transport in neuroprotection and regeneration. Dev Neurobiol. 2018;78(10):998-1010.

25. Smith PD, Sun F, Park KK, Cai B, Wang C, Kuwako K, Martinez-Carrasco I, Connolly L, He Z. SOCS3 deletion promotes optic nerve regeneration in vivo. Neuron. 2009;64(5):617-23.

26. Sun F, Park KK, Belin S, Wang D, Lu T, Chen G, Zhang K, Yeung C, Feng G, Yankner BA, et al. Sustained axon regeneration induced by co-deletion of PTEN and SOCS3. Nature. 2011;480(7377):372-5.

27. de Lima S, Koriyama Y, Kurimoto T, Oliveira JT, Yin Y, Li Y, Gilbert HY, Fagiolini M, Martinez AM, Benowitz L. Full-length axon regeneration in the adult mouse optic nerve and partial recovery of simple visual behaviors. Proc Natl Acad Sci U S A. 2012;109(23):9149-54.

28. Labrador-Velandia S, Alonso-Alonso ML, Alvarez-Sanchez S, GonzalezZamora J, Carretero-Barrio I, Pastor JC, Fernandez-Bueno I, Srivastava GK. Mesenchymal stem cell therapy in retinal and optic nerve diseases: an update of clinical trials. World J Stem Cells. 2016;8(11):376-83.

29. Zarbin M. Cell-based therapy for degenerative retinal disease. Trends $\mathrm{Mol}$ Med. 2016;22(2):115-34.

30. Zaverucha-do-Valle C, Mesentier-Louro L, Gubert F, Mortari N, Padilha AB, Paredes BD, Mencalha A, Abdelhay E, Teixeira C, Ferreira FG, et al. Sustained effect of bone marrow mononuclear cell therapy in axonal regeneration in a model of optic nerve crush. Brain Res. 2014;1587:54-68.

31. Mesentier-Louro LA, Teixeira-Pinheiro LC, Gubert F, Vasques JF, Silva-Junior AJ, Chimeli-Ormonde L, Nascimento-Dos-Santos G, Mendez-Otero R, Santiago MF. Long-term neuronal survival, regeneration, and transient target reconnection after optic nerve crush and mesenchymal stem cell transplantation. Stem Cell Res Ther. 2019;10(1):121.

32. Li N, Li XR, Yuan JQ. Effects of bone-marrow mesenchymal stem cells transplanted into vitreous cavity of rat injured by ischemia/reperfusion. Graefes Arch Clin Exp Ophthalmol. 2009;247(4):503-14.

33. Harper MM, Grozdanic SD, Blits B, Kuehn MH, Zamzow D, Buss JE, Kardon $\mathrm{RH}$, Sakaguchi DS. Transplantation of BDNF-secreting mesenchymal stem cells provides neuroprotection in chronically hypertensive rat eyes. Invest Ophthalmol Vis Sci. 2011;52(7):4506-15.

34. Emre E, Yuksel N, Duruksu G, Pirhan D, Subasi C, Erman G, Karaoz E. Neuroprotective effects of intravitreally transplanted adipose tissue and bone marrow-derived mesenchymal stem cells in an experimental ocular hypertension model. Cytotherapy. 2015;17(5):543-59.

35. Johnson TV, Bull ND, Hunt DP, Marina N, Tomarev SI, Martin KR. Neuroprotective effects of intravitreal mesenchymal stem cell transplantation in experimental glaucoma. Invest Ophthalmol Vis Sci. 2010; 51(4):2051-9.

36. Watson N, Divers R, Kedar R, Mehindru A, Mehindru A, Borlongan MC, Borlongan CV. Discarded Wharton jelly of the human umbilical cord: a viable source for mesenchymal stromal cells. Cytotherapy. 2015;17(1):18-24.

37. Fong CY, Chak LL, Biswas A, Tan JH, Gauthaman K, Chan WK, Bongso A Human Wharton's jelly stem cells have unique transcriptome profiles compared to human embryonic stem cells and other mesenchymal stem cells. Stem Cell Rev. 2011;7(1):1-16

38. Vallabhaneni KC, Penfornis P, Dhule S, Guillonneau F, Adams KV, Mo YY, Xu $\mathrm{R}$, Liu Y, Watabe K, Vemuri MC, et al. Extracellular vesicles from bone marrow mesenchymal stem/stromal cells transport tumor regulatory microRNA, proteins, and metabolites. Oncotarget. 2015;6(7):4953-67.

39. Giebel B, Kordelas L, Börger V. Clinical potential of mesenchymal stem/ stromal cell-derived extracellular vesicles. Stem Cell Investig. 2017;4(10):84

40. Yang Y, Ye Y, Su X, He J, Bai W, He X. MSCs-derived exosomes and neuroinflammation, neurogenesis and therapy of traumatic brain injury. Front Cell Neurosci. 2017;11:55.

41. Teixeira-Pinheiro LC, Toledo MF, Nascimento-Dos-Santos G, Mendez-Otero R, Mesentier-Louro LA, Santiago MF. Paracrine signaling of human mesenchymal stem cell modulates retinal microglia population number and phenotype in vitro. Exp Eye Res. 2020;200:108212.

42. Alencar AKN, Pimentel-Coelho PM, Montes GC, da Silva MMC, Mendes LVP, Montagnoli TL, Silva AMS, Vasques JF, Rosado-de-Castro PH, Gutfilen B, et al. Human mesenchymal stem cell therapy reverses Su5416/hypoxia-induced pulmonary arterial hypertension in mice. Front Pharmacol. 2018:9:1395.

43. Bodart-Santos V, de Carvalho LRP, de Godoy MA, Batista AF, Saraiva LM, Lima LG, Abreu CA, De Felice FG, Galina A, Mendez-Otero R, et al. Extracellular vesicles derived from human Wharton's jelly mesenchymal stem cells protect hippocampal neurons from oxidative stress and synapse damage induced by amyloid- $\beta$ oligomers. Stem Cell Res Ther. 2019;10(1):332.

44. Mello TG, Rosado-de-Castro PH, Campos RMP, Vasques JF, Rangel-Junior WS, Mattos R, Puig-Pijuan T, Foerster BU, Gutfilen B, Souza SAL, et al. Intravenous human umbilical cord-derived mesenchymal stromal cell administration in models of moderate and severe intracerebral hemorrhage. Stem Cells Dev. 2020;29(9):586-98.

45. Godoy MA, Saraiva LM, Carvalho LRP, Vasconcelos-Dos-Santos A, Beiral HJV, Ramos AB, Silva LRP, Leal RB, Monteiro VHS, Braga CV, et al. Mesenchymal stem cells and cell-derived extracellular vesicles protect hippocampal neurons from oxidative stress and synapse damage induced by amyloid- $\beta$ oligomers. J Biol Chem. 2017;293(6):1957-75.

46. Yin Y, Cui Q, Li Y, Irwin N, Fischer D, Harvey AR, Benowitz LI. Macrophage-derived factors stimulate optic nerve regeneration. J Neurosci. 2003;23(6):2284-93.

47. Nascimento-Dos-Santos G, Teixeira-Pinheiro LC, da Silva-Junior AJ, Carvalho LRP, Mesentier-Louro LA, Hauswirth WW, Mendez-Otero R, Santiago MF, Petrs-Silva $\mathrm{H}$. Effects of a combinatorial treatment with gene and cell therapy on retinal ganglion cell survival and axonal outgrowth after optic nerve injury. Gene Ther. 2019;27(1-2):27-39.

48. Leon S, Yin Y, Nguyen J, Irwin N, Benowitz LI. Lens injury stimulates axon regeneration in the mature rat optic nerve. J Neurosci. 2000;20(12):4615-26.

49. Giraldi-Guimarães A, de Bittencourt-Navarrete RE, Nascimento ICC, Salazar PR, Freitas-Campos D, Mendez-Otero R. Postnatal expression of the plasticity-related nerve growth factor-induced gene A (NGFI-A) protein in the superficial layers of the rat superior colliculus: relation to $\mathrm{N}$-methyl-daspartate receptor function. Neuroscience. 2004;129(2):371-80.

50. Mesentier-Louro LA, De Nicolo S, Rosso P, De Vitis LA, Castoldi V, Leocani L, Mendez-Otero R, Santiago MF, Tirassa P, Rama P, et al. Time-dependent nerve growth factor signaling changes in the rat retina during optic nerve crushinduced degeneration of retinal ganglion cells. Int J Mol Sci. 2017;18(1):98.

51. Cimino M, Goncalves RM, Barrias CC, Martins MCL. Xeno-free strategies for safe human mesenchymal stem/stromal cell expansion: supplements and coatings. Stem Cells Int. 2017;2017:6597815.

52. Sanes JR, Masland RH. The types of retinal ganglion cells: current status and implications for neuronal classification. Annu Rev Neurosci. 2015:38:221-46.

53. Duan X, Qiao M, Bei F, Kim IJ, He Z, Sanes JR. Subtype-specific regeneration of retinal ganglion cells following axotomy: effects of osteopontin and mTOR signaling. Neuron. 2015;85(6):1244-56. 
54. Tran NM, Shekhar K, Whitney IE, Jacobi A, Benhar I, Hong G, Yan W, Adiconis X, Arnold ME, Lee JM, et al. Single-cell profiles of retinal ganglion cells differing in resilience to injury reveal neuroprotective genes. Neuron. 2019;104(6):1039-55 e1012.

55. Cole AJ, Saffen DW, Baraban JM, Worley PF. Rapid increase of an immediate early gene messenger RNA in hippocampal neurons by synaptic NMDA receptor activation. Nature. 1989;340(6233):474-6.

56. Abraham WC, Mason SE, Demmer J, Williams JM, Richardson CL, Tate WP, Lawlor PA, Dragunow M. Correlations between immediate early gene induction and the persistence of long-term potentiation. Neuroscience. 1993;56(3):717-27.

57. Donders R, Bogie JFJ, Ravanidis S, Gervois P, Vanheusden M, Maree R, Schrynemackers M, Smeets HJM, Pinxteren J, Gijbels K, et al. Human Wharton's jelly-derived stem cells display a distinct immunomodulatory and proregenerative transcriptional signature compared to bone marrowderived stem cells. Stem Cells Dev. 2018;27(2):65-84.

58. Hill AJ, Zwart I, Tam HH, Chan J, Navarrete C, Jen LS, Navarrete R. Human umbilical cord blood-derived mesenchymal stem cells do not differentiate into neural cell types or integrate into the retina after intravitreal grafting in neonatal rats. Stem Cells Dev. 2009;18(3):399-409.

59. Abreu SC, Weiss DJ, Rocco PR. Extracellular vesicles derived from mesenchymal stromal cells: a therapeutic option in respiratory diseases? Stem Cell Res Ther. 2016;7(1):53.

60. Mead B, Tomarev S. Bone marrow-derived mesenchymal stem cells-derived exosomes promote survival of retinal ganglion cells through miRNAdependent mechanisms. Stem Cells Transl Med. 2017:6(4):1273-85.

61. Wang Y, Wu H, Yang Z, Chi Y, Meng L, Mao A, Yan S, Hu S, Zhang J, Zhang $Y$, et al. Human mesenchymal stem cells possess different biological characteristics but do not change their therapeutic potential when cultured in serum free medium. Stem Cell Res Ther. 2014;5(6):132.

62. Lim JH, Stafford BK, Nguyen PL, Lien BV, Wang C, Zukor K, He Z, Huberman $A D$. Neural activity promotes long-distance, target-specific regeneration of adult retinal axons. Nat Neurosci. 2016;19(8):1073-84

63. Coullon GS, Jiang F, Fine I, Watkins KE, Bridge H. Subcortical functional reorganization due to early blindness. J Neurophysiol. 2015;113(7):2889-99.

64. Zhao T, Li Y, Tang L, Li Y, Fan F, Jiang B. Protective effects of human umbilical cord blood stem cell intravitreal transplantation against optic nerve injury in rats. Graefes Arch Clin Exp Ophthalmol. 2011;249(7):1021-8.

65. Jiang B, Zhang $P$, Zhou D, Zhang J, Xu X, Tang L. Intravitreal transplantation of human umbilical cord blood stem cells protects rats from traumatic optic neuropathy. PLoS One. 2013;8(8):e69938.

66. Chen M, Xiang Z, Cai J. The anti-apoptotic and neuro-protective effects of human umbilical cord blood mesenchymal stem cells (hUCB-MSCs) on acute optic nerve injury is transient. Brain Res. 2013;1532:63-75.

67. Millán-Rivero JE, Nadal-Nicolás FM, García-Bernal D, Sobrado-Calvo P, Blanquer M, Moraleda JM, Vidal-Sanz M, Agudo-Barriuso M. Human Wharton's jelly mesenchymal stem cells protect axotomized rat retinal ganglion cells via secretion of anti-inflammatory and neurotrophic factors. Sci Rep. 2018;8(1):16299.

68. Zwart I, Hill AJ, Al-Allaf F, Shah M, Girdlestone J, Sanusi ABR, Mehmet H, Navarrete R, Navarrete C, Jen L-S. Umbilical cord blood mesenchymal stromal cells are neuroprotective and promote regeneration in a rat optic tract model. Exp Neurol. 2009;216(2):439-48.

\section{Publisher's Note}

Springer Nature remains neutral with regard to jurisdictional claims in published maps and institutional affiliations.

Ready to submit your research? Choose BMC and benefit from:
- fast, convenient online submission
- thorough peer review by experienced researchers in your field
- rapid publication on acceptance
- support for research data, including large and complex data types
- gold Open Access which fosters wider collaboration and increased citations
- maximum visibility for your research: over 100M website views per year
At BMC, research is always in progress.
Learn more biomedcentral.com/submissions

